\title{
The Book of Pop Up Augmented Reality to Increase Focus and Object Recognition Capabilities for Children with Autism
}

\author{
Mohammad Arief Nazaruddina, Mohammad Efendi ${ }^{\mathrm{b}}$ \\ ${ }^{a}$ Brawijaya University of Malang \\ ${ }^{\mathrm{b}}$ State University of Malang \\ Email: annajihad@gmail.com
}

\begin{abstract}
One of the extreme behavioral indicators experienced by children with autism is the difficulty of focusing through the object carefully, especially the objects that cannot attract their attention. To overcome these obstacles, medium or media that can bridge the characteristics of children with autism is needed. Books with pop up augmented reality can be a solution. The purpose of this research is to describe the feasibility of the use of books with pop up augmented reality format to improve the focus and recognition of objects for children with autism. Therefore, the design used in this research is planning design, and the respondents are students of SDLB Laboratorium of Autism UM. Based on the results of the research, the utilization of pop up augmented reality book was able to increase the autistic student appreciation on objects introduced to him. The indicator can be seen from the increased interest in design, the duration of observation, exploration of curiosity, mastery of message content, communication when observing objects or thing introduced to them.
\end{abstract}

Keywords: pop-up augmented reality, autism, object recognition

Looking closely at the physical performance seen in children with autism and normal children, if we do not pay attention to the behaviors that the child with autism show, we may have difficulty recognizing the difference. Some children with mild autism when performing certain activities are not impressed that the person concerned is autistic. Children identified as autistic doesn't appear to have a fundamental suspicion that they resemble others and others just like them. Conditions experienced by children with autism begin to be identified when the concerned involved in interaction and social communication. The apparent differences in children with autism and normal children, systematically behave in many ways of interact, and often the behaviors played by children with autism doesn't reflect the capacity of the child according to their chronological age or mental age. Generally, Behaviors of autistic children are identified differently normally, some of them are: (1) ignoring others, (2) appearing insensitive to the needs, feelings and thoughts of others, (3) don't want to meet or express facial expressions when speaking, (4) don't like to touch (don't want to hug or hold), (5) can not cooperate, share or wait their turn, (6) prefer to play alone, and (7) less interest in games that must use imagination. Similarly, the inability to communicate and speak, the indications are: (1) slow speech, (2) having problems in speaking and understanding of people's conversation, (3) unable to communicate well, (4) speaking in strange tones, such as singing or speaking of robots, (5) difficult to start a conversation, (6) often repeating the same word but not understanding what it means. However, it should be noted that some of them are mentally late in the same mental age, but not least among those with above-average mental-intellectual abilities, and can develop normally.

The American Psychiatric Assocation (APA) identifies on the base appearance, autism children appear to have social weaknesses shown through their inability to build social and emotional relationships with others, the field of communication is shown in the development of obstructed language and speech, and the emergence of a pattern that is maintained and repeated in behavior, interests and activities (Hildayani, 2007). This condition occurs because children with autism are selectively over-stimulated, lacking the motivation to explore the environment, lack of self-stimulation responses that interfere with social integration, and have a unique response to reinforcement, particularly reinforcements of self-stimulation (Handoyo, 2003), no empathy, lacking the ability to develop friendships, his speech is accentuating knowledge / recurring, poor non-verbal communication, extraordinary absorption of certain subjects, odd attitudes (Atwood, 2005). The ability to socialize this indication happens gradually causing them far behind compared to peers (Martin, 2010). 
Table 1. Assessment Criteria Guidelines

\begin{tabular}{llllll}
\hline $\begin{array}{l}\text { Interest } \\
\text { to the design }\end{array}$ & $\begin{array}{l}\text { Duration of } \\
\text { observation }\end{array}$ & $\begin{array}{l}\text { Exploration of Curios- } \\
\text { ity }\end{array}$ & $\begin{array}{l}\text { Mastery of Message } \\
\text { Contents }\end{array}$ & $\begin{array}{l}\text { Communica- } \\
\text { tion }\end{array}$ & Score \\
\hline $\begin{array}{l}\text { Very enthusi- } \\
\text { astic }\end{array}$ & $>30$ minutes & $\begin{array}{l}\text { Observation of the object } \\
\text { is very detailed }\end{array}$ & $\begin{array}{l}\text { The memory of the ob- } \\
\text { ject is very good }\end{array}$ & $\begin{array}{l}\text { Very respon- } \\
\text { sive }\end{array}$ & 4 \\
$\begin{array}{l}\text { Quite } \\
\text { Enthusiastic }\end{array}$ & $21-30$ minutes & $\begin{array}{l}\text { Observation of the object } \\
\text { is quite detailed }\end{array}$ & $\begin{array}{l}\text { The memory of the ob- } \\
\text { ject is quite good }\end{array}$ & $\begin{array}{l}\text { Quite } \\
\text { responsive }\end{array}$ & 3 \\
$\begin{array}{llll}\text { Less enthusi- } \\
\text { astic }\end{array}$ & $11-20$ minutes & $\begin{array}{l}\text { Observation of the object } \\
\text { is less detail }\end{array}$ & $\begin{array}{l}\text { The memory of the ob- } \\
\text { ject is not good }\end{array}$ & $\begin{array}{l}\text { Less respon- } \\
\text { sive }\end{array}$ & 2 \\
Not enthusiastic & $<10$ minutes & $\begin{array}{l}\text { Observation of objects is } \\
\text { not detailed }\end{array}$ & $\begin{array}{l}\text { The memory of the ob- } \\
\text { ject is very bad }\end{array}$ & $\begin{array}{l}\text { Not } \\
\text { responsive }\end{array}$ \\
\hline
\end{tabular}

According to the World Health Organization (WHO) identification, general behavioral indicators that often appear in autistic children include: (1) language or communication is flat, speech a little bit or even not speech, often repeating words, sentences with weird vowels (2) lack of responsiveness in relationships with others, (3) relation with the environment shows rigid routines, exhibits a very inflexible interest, (4) responses to sensory stimuli often seem deaf, frantic to sound - a particular sound, very sensitive to sound, playing with light or reflection, playing withdrawal when touched, (5) behavioral gaps that are sometimes very good or very late, for example clever reading but not understanding the meaning, clever drawing in detail but not able to button clothes, good at puzzles but very difficult to follow orders. However, in fact, not all of these symptoms are present in autistic individuals, because the symptoms seen in autistic children are so varied that no autistic child is really the same in all of his behavior. Whatever the condition, an attempt to diagnose early childhood is suspected to have autism, is the right step toward the effort to autism children can be handled immediately through the process of learning intervention in an integrated manner. Thus more open opportunities change toward normal behavior. Pharmacologic and nonpharmacologic therapies are indicative of anxiety, severe agitapsychomotor, extreme sensitivity to environmental stimuli, but they do not significantly reduce the symptoms of autism (Hasdianah, 2013). Treatment is usually tailored to the needs of the child. Many psychosocial interventions have some positive evidence. Some forms of treatment are better, but their clinical outcomes are mostly tentative. Specially sustained education programs and early behavioral therapy interventions can help autistic get personal care, social skills, work skills, reduce symptoms severity and maladaptive behavior.

One effort to provide an accurate education service for autistic children for self-development requires strategy and media (manual and digital) as a tool for effective interaction between teachers and students with autism. By considering its characteristics, the use of manual and digital combination learning materials designed in pop up augmented in reality format can be a means of educative therapy for autistic children. Because the learning materials in pop up augmented reality format, viewed from the technical and visual side can be very revolutionary. This media is able to make the reader dissolved emotionally and feel when the interaction with the object of the story, the reader seems to be part of the amazing thing, because the reader feels a role when starting to open the book page (Sabuda, 2005).

Based on these thoughts, this research will explicitly expose the essence of the presentation of pop up augmented reality books to fill the gap of interesting, innovative, and modern learning materials for children with autism in elementary school level. The background of the design and testing of books in pop up augmented reality format is all kinds of book (story or encyclopedia) in circulation only present a visual flat and provide graphical information only, without highlighting the interactive side of the reader.

\section{METHOD}

The purpose of this research is to analyze prototype of teaching materials in the form to improve the power of focus and recognition of objects in children with autism by utilizing books with pop-up augmented reality format. The methodology used in this research is a descriptive procedural design, design model that outlines the steps to produce a product. Procedural step design research begins with the identification of the problems studied through reference-related and empirical data in the field. 
Table 2. Recapitulation of prototype trial results as limited

\begin{tabular}{|c|c|c|c|c|c|c|c|c|c|c|c|c|c|}
\hline \multirow[t]{2}{*}{ No } & \multirow{2}{*}{$\begin{array}{l}\text { Respon- } \\
\text { dents }\end{array}$} & \multicolumn{2}{|c|}{$\begin{array}{l}\text { Interest to the } \\
\text { Design }\end{array}$} & \multicolumn{2}{|c|}{$\begin{array}{l}\text { Duration of } \\
\text { observation }\end{array}$} & \multicolumn{2}{|c|}{$\begin{array}{l}\text { Exploration of } \\
\text { Curiosity }\end{array}$} & \multicolumn{2}{|c|}{$\begin{array}{l}\text { Mastery of } \\
\text { Message Con- } \\
\text { tents }\end{array}$} & \multicolumn{2}{|c|}{$\begin{array}{l}\text { Communica- } \\
\text { tion }\end{array}$} & \multicolumn{2}{|l|}{ Total } \\
\hline & & Before & After & Before & After & Before & After & $\begin{array}{l}\mathrm{Be}- \\
\text { fore }\end{array}$ & After & $\begin{array}{l}\text { Be- } \\
\text { fore }\end{array}$ & After & $\begin{array}{l}\text { Be- } \\
\text { fore }\end{array}$ & After \\
\hline 1 & Wim & 2 & 4 & 2 & 4 & 2 & 4 & 1 & 4 & 2 & 4 & 9 & 20 \\
\hline 2 & Isa & 1 & 4 & 2 & 4 & 3 & 4 & 1 & 4 & 3 & 4 & 10 & 20 \\
\hline 3 & Dav & 2 & 4 & 1 & 4 & 2 & 4 & 3 & 4 & 2 & 4 & 10 & 20 \\
\hline 4 & Aza & 1 & 3 & 1 & 4 & 1 & 3 & 1 & 3 & 1 & 3 & 5 & 16 \\
\hline \multirow{2}{*}{\multicolumn{2}{|c|}{$\begin{array}{l}\text { Amount } \\
\% \\
\end{array}$}} & 6 & 15 & 6 & 16 & 8 & 15 & 6 & 15 & 8 & 15 & 34 & 76 \\
\hline & & 37.5 & 93.75 & 37.5 & 100 & 50 & 93.75 & 37.5 & 93.75 & 50 & 93.75 & 42.5 & 95 \\
\hline \multicolumn{2}{|c|}{$\begin{array}{l}\text { Difference } \\
(\%)\end{array}$} & \multicolumn{2}{|c|}{56.25} & \multicolumn{2}{|c|}{62.5} & \multicolumn{2}{|c|}{43.75} & \multicolumn{2}{|c|}{56.25} & \multicolumn{2}{|c|}{43.75} & \multicolumn{2}{|c|}{52.5} \\
\hline
\end{tabular}

Based on these data, then analyzed critically and synthesized in the form of design concepts relevant to the needs of the subject. Based on the characteristics of the media to be produced as well as considering the goals, strategies, creative programs, then in the concept of designing a book media with pop up augmented reality format should pay attention to visual messages and verbal messages. After the media design is created, the evaluation of the products that eventually communicated to the audience. Optimization of the design is done after the evaluation phase through the prototype feasibility test.

The subjects of this research were autistic students SDLB Laboratorium State University of Malang identified as follows: lightweight autistic students who have no intellectual barriers, can communicate well, can understand the command, and can read the book. The data collection technique was done by recording the student's response on a certain period of time, ie the students before being given the book and after being given the book with pop up augmented reality format. To achieve these objectives, the data collection instrument used in this research was in the form of observation sheet and interview result. For observation sheets of assessment criteria and assessed aspects, as follows table 1 .

\section{FINDINGS AND DISCUSSION}

\section{Findings}

The data was collected through written documents and direct records, after selection and verification, the results can be presented in the following description in table 2 .

Based on Table 2, it is known that the result of prototype feasibility test of instructional materials in the form of book with pop up augmented reality as a whole has increased significantly (52.5\%). Some of the indicators used as the basis for the assessment of the prototype of teaching materials in the form of pop up augmented reality books include: interest in design (increased by $56.25 \%$ ), observation duration (increased by $62.5 \%$ ), exploration of interest $(43.75 \%$ ), mastery of message content (increased by $56.25 \%$ ), and communication (43.75\% increase).

Qualitative comment after the test of book with pop up augmented reality format can be interpreted that prototype of instructional materials in the form of book with pop up augmented reality format in general according to the respondent (4 students) can be a good, unique and fun learning media. This media can give the impression of experience to the child to interact directly with the object. In terms of concept design, some of the indicators used as the basis for the assessment of prototype book with pop up augmented reality format are very familiar, funny and adorable because the background looks original as if the animal lives in the book naturalye. Similarly, from the content side, from the students' responses, the prototype looks easy to learn and understand because the information support is quite complete.

The respondents'(2 teachers)qualitativeassessment result compilation of the $s$ of the of the prototype of the book with the format of pop up augmented reality, in general according to the respondents' ratings (Teachers), the book can be categorized very well. Through this media students are easier and faster to learn something because it is assisted by a unique visual. The impact can provide excellent learning motivation to the students, so they always give priority to reading as entertainment. From the design side, pop up augmented reality media already represents the child's visual needs in the learning process as this book accentuates the visual side of the text . The design style featured in the pop up augmented reality is able to give a strong stimulus for children to use it because not only the visual is easily digested by children but also the surprising element of the book makes the child 
amazed at his first sight. While the displayed content is quite interesting because it already represents the type of animal that is very popular in the community, easy to be understood because the language used is also very familiar.

\section{Discussion}

Some efforts to empower autistic children through education require high cost considering that the autism spectrum varies and requires different educational tools. This condition often presents counterproductive thinking among educational bureaucrats if it touches on the cost of education for children with autism. Because the cost incurred for the empowerment of children with autism or other special needs children is considered not worth the resulting productivity contribution (Efendi, 1999).

Whatever the problem, they need qualitative education services as mandated by Law no. 20 of 2003 on the National Education System article 32. The implication is that children with special needs including children with autism as well as the other normal children need the same opportunities. the .

Based on the result of the experimental analysis, the design of prototype of learning media in the form of pop up augmented reality book is overall able to increase the autism student appreciation significantly (Table 2). Some of the indicators used as the basis for the assessment of the prototype of teaching materials in the form of pop up augmented reality books include: interest in design, product observation duration, curiosity exploration, and mastery of message content increased above $50 \%$ average, while for communicative value of product below 50\%.

The eligibility of a pop-up book as a learning bridge has $3 \mathrm{D}$ illustrations, which can give the impression that pop-up books can stand up and can be driven by the reader. At that time, pop ups can provide a more interesting visualization of the story. Starting from the view of images that look more have dimensions, images that can move when the page is opened or the part is shifted, there are parts that can change shape, have a texture like the original object, even some parts that can issue sound. Things like this that make the story presented more fun and interesting to enjoy. Another fact that makes pop ups interesting and different from story books with ordinary illustrations, pop ups will surprise every page and can invite amazement when the page is loaded. Pop up books have the ability to reinforce the impression to be conveyed in a story, so nuance more felt. Dimensional visual appearance makes the story even more noticeable, especially with the surprises given in each page. Images presented can suddenly appear from behind a page or a building can stand majestically in the middle of the page. By way of this visualization, the impression you want to display can be more conveyed (Online; www.robertsabuda. com).

Augmented reality as a technology combines two-dimensional and three-dimensional virtual objects into a real three-dimensional environment. Then, these virtual objects are projected in real time. Unlike virtual reality that completely replaces reality, augmented reality complements reality. This makes augmented reality appropriate as a tool to help the user's perception and interaction with the real world. Information displayed by virtual objects helps users carry out activities in the real world. Augmented reality itself as the work of the development of human thinking in creating a new technology, it can also give a positive influence in its use (Nazaruddin, 2016). In addition, augmented reality can be accessed and modified in such a way that can be enjoyed by the general public. However, in reality there are still many people who do not understand and know what augmented reality is. Whereas augmented reality is a technology that can bridge between people with objects, so it looks more interactive and help human life with innovations that are always there.

The suitability of designing book products with pop up augmented reality format shows that this product substantially needs to be developed further as an alternative media to support learning. The existence of the media in the books form with all kinds of variations to support learning in children with special needs, especially children with autism, still remain an important part. The results of national survey of 14 provinces on the implementation of curriculum 2013 special education field, the use of textbooks as the most classified traditional media is still the main menu of learning support for children with special needs, and in quantity according to the recognition of new principals meet $21 \%$ of the needs. While in terms of technical quality according to the stakeholder assessment the textbooks of children with special needs can meet $66 \%$ of the established standard (Efendi, 2016). On that basis, it is undeniable that textbooks with pictorial formats are very effective in improving the understanding of deaf students, especially in terms of the ability to listen and understand the meaning of language, the ability to read and understand the meaning of language, the ability to write and understand the meaning of language (Efendi, 2017) . In other formats, picture module books are effective in science subjects in deaf children at SDLB (Marzuqi \& Sihkabuden, 2017).

Based on the experience, book products with pop-up augmented reality format as an innovation of two-dimensional media that fluctuate into 3-dimensional media, then with the help of digital technology metamorphose into new media with 
multimedia format. With the continuous development of pop-up and augmented reality media into textbooks, teachers assume that this media will provide a positive value for them in digesting information to learn something new, because that is presented enough to attract the attention of children. Character design and color layouts used in this format book, able to represent visual works that can be enjoyed by children with special needs. For visual in augmented reality itself also has been able to distract children's attention to the book served (Nazaruddin, 2016).

Multimedia in pop up augmented reality for teachers, when applied to textbooks is very supportive in teaching and learning process in autistic children, because autistic children basically need a lot of recognition of an object. More and more similar media applications in autism learning have been found to stimulate the birth of the conversation among them (Jusoh \& Majid, 2017). Similarly, the use of interactive multimedia animation in learning has a positive effect, ie, the resulting effect not only increases students' interest and motivation, but also indirectly improves the ability of children with learning disabilities in reading (Yahya and Tahar, 2017). Departing from the description, the intervention of pop-up augmented reality technology in textbook certainly makes it easier for students to understand and see the proportion of real formation of the object delivered.

Keep in mind, the book Pop Up Augmented Reality as a product of technology originally produced to meet the recreative device can be used as a medium of learning in children with special needs, especially children with autism. Being viewed technically and visually the book pop upaugmented reality as educational material is quite revolutionary, because in addition to having advantages that highlight the impression to be conveyed in a story that makes readers dissolved emotionally. Pop upaugmented reality books will bring readers to feel they can interact with story objects, "readers seem to be part of that amazing thing, because they feel they have a role when they open a book page" (Sabuda, 2005).

On that basis, the design style shown in pop up augmented reality can stimulate the child, because in addition to the visual easily digested by children, also pop up augmented reality has a surprising element that makes children amazed at their first sight. Similarly, from the content side, the content displayed is quite interesting because it already represents the type of animal that is very popular in the community, easy to understand and understand because the language used is very familiar.

\section{CONCLUSION AND SUGGESTION}

\section{Conclusion}

The impaired communication and interaction in children with autism with variations often make teachers difficult do learning intervention. The presence of prototype of media product in the form of pop up augmentend reality book with all its advantages based on the result of feasibility test has gained positive appreciation. Some of the indicators used as the basis for the assessment of the feasibility of prototype teaching materials in the form of book with pop up augmented reality format include: interest in design, product observation duration, curiosity exploration, and mastery of message content and communicative products.

\section{Suggestion}

To obtain maximum results on the utilization of media in the form of popup augmentend reality book with all the advantages of the children with special needs, it is suggested that the implementation needs to assist teachers of special education trained in the utilization of information technology and communication, especially mastery of gadgets. Please note, the implementation of this technology attention of children more distracted to object augmented reality than to its reading content. So the role of accompanying teachers is needed to assist them in conveying the information contained in the book.

\section{REFERENCE}

Atwood, T. (2005). Sindrom Asperger. Jakarta: PT Serambi Ilmu Semesta

Direktorat PSLB (2004). Prioritas Kebijakan Pendidikan Bagi Anak autis. Jakarta: Direktorat PSLB Kemendiknas Republik Indonesia.

Efendi, M. (1999). Peranserta Pendidikan Luar Sekolah Dalam Pengembangan Sumberdaya Manusia Penyandang Cacat Melalui Pemberdayaan Kemandirian. Jurnal VISI, 1(1).

Efendi, M. (2016). Pengantar Pendidikan Anak Berkelainan (Translate: Introduction to Education for Special Need Child). Malang: Universitas Negeri Malang Press.

Efendi, M. (2017) The Effectiveness of the Pictorial Book to Improve the Understanding of Deaf Students About Nature and Environment in Elementary School. Journal of ICSAR, 1(2), 103-108. 
Handoyo. (2003). Autisma: Petunjuk Praktis dan Pedoman Materi Untuk Mengajar Anak Autis dan Perilaku Lain. Jakarta: PT Bhuana Ilmu.

Hasdianah (2013). Autis Pada Anak: Pencegahan, Perawatan, dan Pengobatan. Yogyakarta: Nuha Medika

Hildayani, R. (2007). Penanganan Anak Berkebutuhan Khusus. Jakarta: Universitas Terbuka.

Jusoh, W., \& Majid, R. A. (2017). Using Picture Exchange Communication System To Improve Speech Utterance Among Children With Autism. Journal of ICSAR, 1(1), 46-49.

Marzuqi, A. \& Sihkabuden (2016). The Development Of Science Learning Module For Childrent With Hearing Impairment. Jurnal Penelitian dan Pengembangan Pendidikan Luar Biasa, 1(1): 7276.
Nazaruddin, M. A. (2016). The Validity of Augmented Realtty Pop Up Books and Papperfold to Increase Interest in Reading in Elementary Deaf Cildren. Prosiding International Conference on Special Education for South Asia Region-6, Kuala Lumpur, 29 Januari 2016

Martin, L. (2010). Financial Palnning for Autis Child. Yogyakarta: Kata Hati

Sabuda, R. (2005). Winter's Tale: An Original Pop-up Journey. New York: Little Simon

Yahya, A., \& Tahar, M. M. (2017). Interactive Animation Multimedia for Knowing the Words $(\mathrm{CV}+\mathrm{CV})$ for Student with Learning Disabilities. Jurnal Penelitian dan Pengembangan Pendidikan Luar Biasa, 4(1), 1-6. 